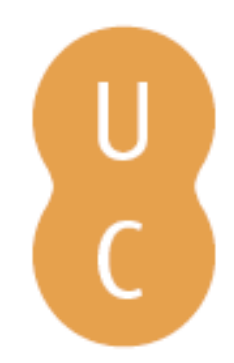

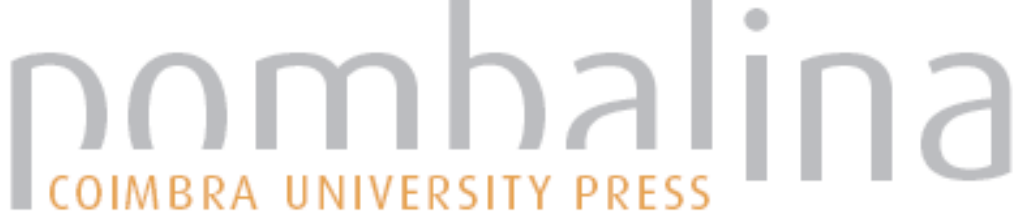

\section{Risk assessment and reflections on socio-economic perception of wildfires at the fireshed level}

\author{
Autor(es): $\quad$ Mitri, George; Bechara, Joseph; Nehme, Maya \\ Publicado por: Imprensa da Universidade de Coimbra \\ URL \\ persistente: URI:http://hdl.handle.net/10316.2/44647 \\ DOI: $\quad$ DOI:https://doi.org/10.14195/978-989-26-16-506_130 \\ Accessed : $\quad$ 26-Apr-2023 14:36:47
}

A navegação consulta e descarregamento dos títulos inseridos nas Bibliotecas Digitais UC Digitalis, UC Pombalina e UC Impactum, pressupõem a aceitação plena e sem reservas dos Termos e Condições de Uso destas Bibliotecas Digitais, disponíveis em https://digitalis.uc.pt/pt-pt/termos.

Conforme exposto nos referidos Termos e Condições de Uso, o descarregamento de títulos de acesso restrito requer uma licença válida de autorização devendo o utilizador aceder ao(s) documento(s) a partir de um endereço de IP da instituição detentora da supramencionada licença.

Ao utilizador é apenas permitido o descarregamento para uso pessoal, pelo que o emprego do(s) título(s) descarregado(s) para outro fim, designadamente comercial, carece de autorização do respetivo autor ou editor da obra.

Na medida em que todas as obras da UC Digitalis se encontram protegidas pelo Código do Direito de Autor e Direitos Conexos e demais legislação aplicável, toda a cópia, parcial ou total, deste documento, nos casos em que é legalmente admitida, deverá conter ou fazer-se acompanhar por este aviso.

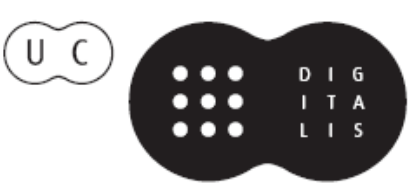




\section{ADVANCES IN}

\section{FOREST FIRE RESEARCH}

\section{8}

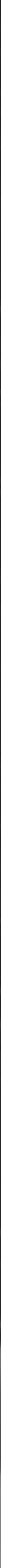




\title{
Risk assessment and reflections on socio-economic perception of wildfires at the fireshed level
}

\author{
George Mitri ${ }^{1 *}$; Joseph Bechara ${ }^{2}$; Maya Nehme ${ }^{2}$ \\ $1 *$ Institute of the Environment, University of Balamand, Kelhat-Koura, Lebanon, \\ \{george.mitri@balamand.edu.lb\} \\ ${ }^{2}$ Lebanon Reforestation Initiative, Hazmieh, Lebanon, \{jbechara@lri-lb.org\}
}

\begin{abstract}
Assessing and evaluating socio-economic perceptions of fire risk and impact can help in the design and development of proper fire risk management and planning. This work aimed at assessing public perception of socio-economic impact of wildfires at the level of a fireshed in Lebanon. The specific objectives were to 1) map fire risk at the fireshed level, and 2) investigate the socio-economic perceptions of key local players involved in fire risk management. The methodology of work comprised 1) delineation of the fireshed of Nahr El Kelb, 2) assessment of fire risk and identification of priority villages/towns for intervention, and 3) development of a targeted socio-economic survey. The delineation of the fireshed started by an initial delineation of the watershed using a Digital Elevation Model. Fire risk was assessed as a product of fire hazard and fire vulnerability. A total of three maps were produced, namely fire hazard, fire vulnerability and fire risk. Identification of priority sites included first the calculation of relative area of high fire risk within each cadastral unit. Consequently, a survey on public socio-economic perception of wildfires was implemented by sampling population in the high risk fire areas. The survey results included answers from 80 respondents on public perception of fire risk, fire damage to constructions and infrastructures, and estimation of fire suppression costs. Other results reflected the public perceptions in relation to direct and indirect effects of fire events in the targeted fireshed. Additional analytical work of questionnaire data will allow for the extraction of specific conclusions and the identification of future steps.
\end{abstract}

Keywords: Fireshed, fire risk, socio-economic perception of wildland fires

\section{Introduction}

A fireshed is conceptually analogous to a watershed. Basically, it surrounds areas of similar wildfire threat where a similar response strategy could influence the wildfire outcome (Bahro et al. 2007). A fireshed assessment though is based on the premise that fuels treatments strategically located to modify fire behavior can positively affect the outcome of a wildland fire by limiting the area severely burned and reducing negative effects on communities, habitat, and watersheds (Finney 2001). Since public and private lands are often intermingled in Lebanon, developing a coordinated program of work requires close collaboration with multiple landowners and interested parties. Hence, two critical pieces must come together to change large wildfire outcomes: (1) collaboration and coordination among agencies, landowners, and the interested public, and (2) on-the-ground implementation of a program of work, which establishes spatial locations, priorities, and schedules for multiple hazardous fuel treatment projects, ideally across all land ownerships in an area. In this context, there is an urgent need to assess and evaluate the local socio-economic perceptions of fire risk and impact in order to design and develop proper fire risk management and planning. Accordingly, this work aimed at assessing public perception of socio-economic impact of wildfires at the level of a fireshed in Lebanon. The specific objectives were to 1) map fire risk at the fireshed level, and 2) investigate the socio-economic perceptions of key local players involved in fire risk management. 


\section{Methodology of work}

This work comprised 1) delineation of the fireshed of Nahr El Kelb, 2) assessment of fire risk and identification of priority villages/towns for intervention, and 3) development of a targeted socioeconomic survey.

\subsection{Study area and dataset description}

The watershed of Jeita has a total size of 40,560 ha and it is located in the center of Lebanon, starting $15 \mathrm{~km}$ northeast of Beirut, on the western exposed side of the Lebanon Mountains (Figure 1). Its central coordinates are 760907.07 and 3763476.89 (UTM zone 36, WGS 84, Zone 36). It ranges between sea level and $2400 \mathrm{~m}$ asl at Mt. Sannine. Steepest reliefs occur along the hillside of fluvial shaped valleys in the southern center of the catchment and along the catchment's northern boundary. The watershed was initially selected for existence of a dense forest cover composed of highly combustible fuel (e.g. pine forests). At the same time the watershed is strategic in providing fresh water supply to the capital city of Beirut (BRG/CDR 2008) and is highly vulnerable to degradation (including risks of fire and pollution).

\subsection{Delineation and topography}

The delineation of the fireshed started by mapping the watershed using a Digital Elevation Model (DEM). The initial area of the watershed was expanded into a fireshed by annexing external areas of administrative units crossed by the borderline of the watershed. As a result, the total area of the identified fireshed was 44,100 ha (i.e., 3,540 ha larger than the size of the initial watershed) comprising a total of 79 villages (Figure 1).

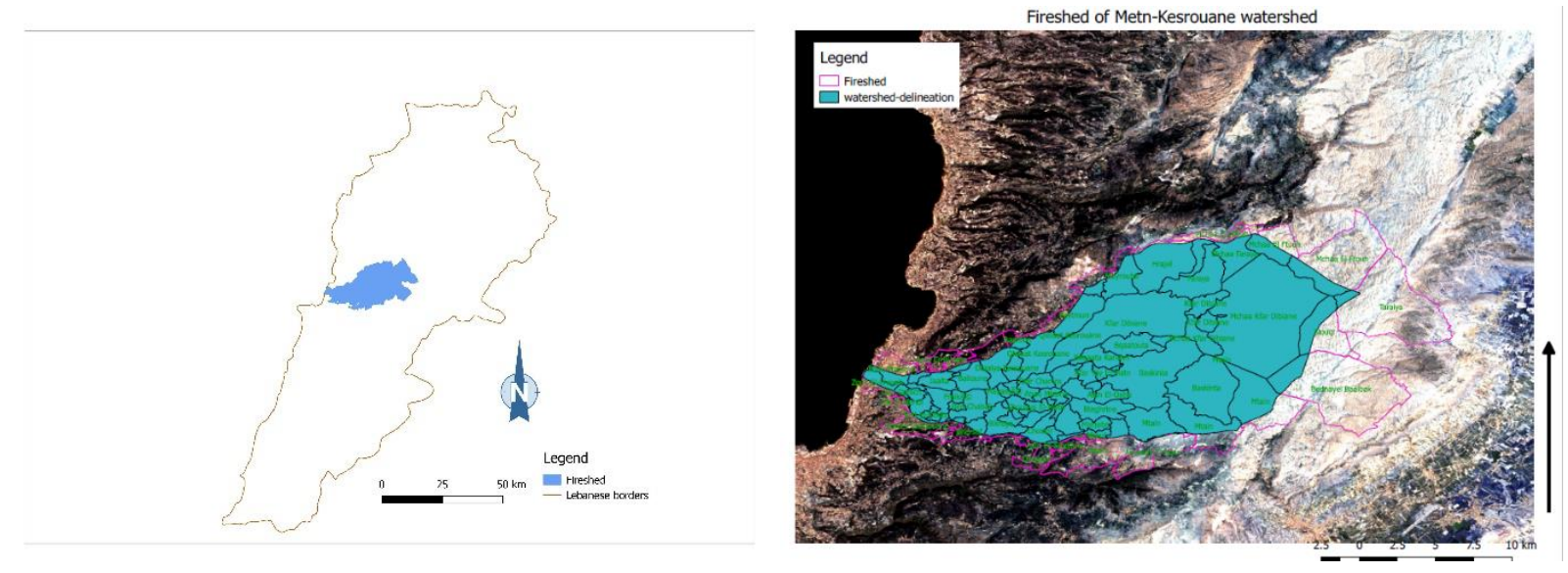

Figure 1 - Location of the fireshed on the map of Lebanon (left) and delineation of the fireshed (right)

\subsection{Fire risk assessment}

An overall wildfire risk assessment was prepared for the fireshed. More specifically, fire risk was assessed as a product of fire hazard and fire vulnerability (Mitri et al. 2015). Fire hazard assessment involved the use of data mainly related to the distribution and density of forest fuel using Landsat satellite imagery. Fire vulnerability was assessed at the cadastral unit level (i.e., village as a mapping unit) and in function of the relative area of hazard per mapping unit. Evaluating fire risk in the area involved the use of a cross mapping between hazard and vulnerability. Consequently, priority sites/villages for intervention were identified by calculating the relative area of high fire risk within each village/town (Table 1). 
Table 1 - Cross-tabular mapping of fire risk

\begin{tabular}{|l|l|l|l|}
\hline HazardIVulnerability & High vulnerability & Moderate vulnerability & Low vulnerability \\
\hline High hazard & High risk & High risk & Moderate risk \\
\hline Moderate hazard & High risk & Moderate risk & Moderate risk \\
\hline Low hazard & Moderate risk & Moderate risk & Low risk \\
\hline No hazard & Moderate risk & Moderate risk & Low risk \\
\hline
\end{tabular}

\subsection{Socio-economic survey}

Consequently, a survey was developed for use in field data collection. More specifically, one questionnaire was addressed to key stakeholders at the local level within the fireshed. Categorization of the survey included the following main sections:

- General questions on main existing forest activities in function of land ownership.

- Perception of wildfire risk and means of reducing hazard.

- Level of knowledge about fire occurrence and fire affected areas within the fireshed.

- Rating of resulting damages, impacts and costs of fires.

Participants to the survey included a total of 80 respondents randomly selected from priority municipalities (i.e., characterized by high risk of fires) and local service departments (e.g., Civil Defense).

\section{Results and discussion}

A total of three maps were produced (Figure 2), namely fire hazard, fire vulnerability, and fire risk (i.e., low risk, moderate risk, high risk, and very high risk).

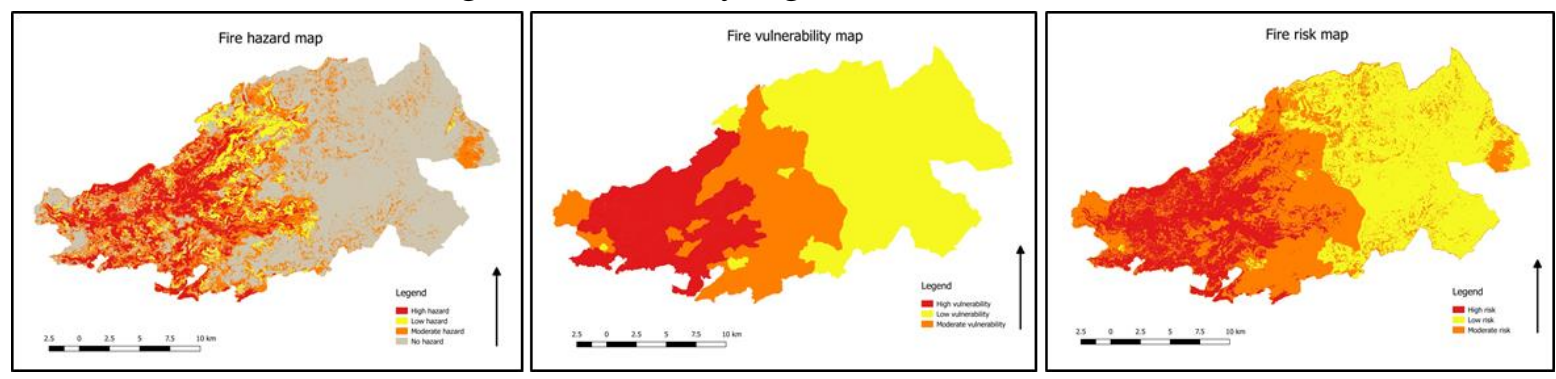

Figure 2 - Fire hazard (left), vulnerability (middle), and risk (right)

Identification of priority sites included first the calculation of relative area of high fire risk within each cadastral unit. As a result, villages including more than $80 \%$ of high risk areas were highlighted on the map. Then, the Wildland-Urban Interface (WUI), described as the area where human development intersects with wildland, was also characterized within the study area. The assessment of wildfire risk in the WUI in Lebanon was based on mapping areas of high risk of fire within a buffer zone of $100 \mathrm{~m}$ from urbanized lands, settlements, and roads. The top 20 villages (i.e., priority sites) including an area above 94 ha of WUI of high risk were identified and located on the map. As a result, a total of three clusters of towns and villages were identified for the survey (Figure 3).

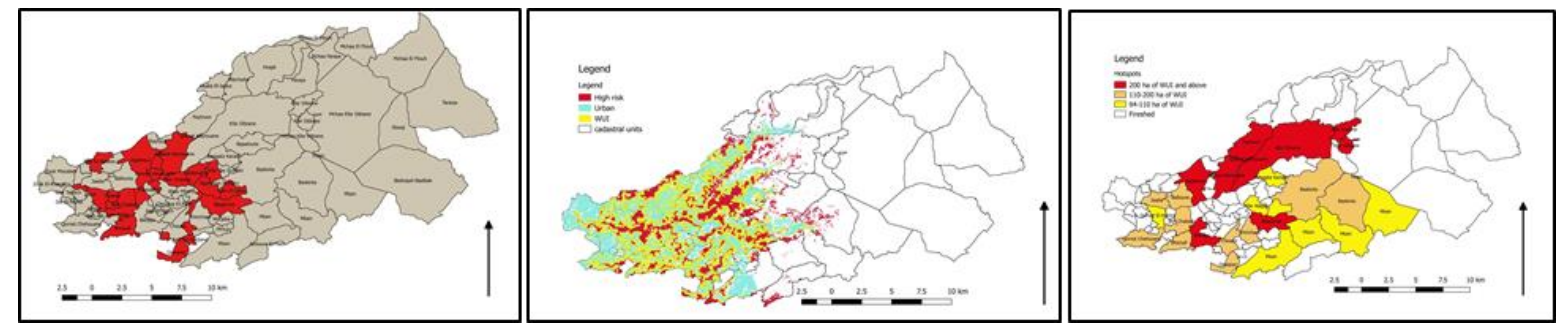

Figure 3 - Villages including more than $80 \%$ of high risk in red (left), WUI (middle), and identified top20 villages (right) 
While respondents were randomly selected from municipalities characterized by high risk of fires, the results of the survey showed that $32 \%$ of sampled population believed that their region is characterized by a high risk of fire, followed by $43 \%$ as moderate risk and $21 \%$ as low risk. Only $4 \%$ of respondents believed of no fire risk in their region. This reflected the need to raise awareness about fire risk for improving readiness and fire risk reduction measures.

Forest land was considered as most prone to fire for $73 \%$ of respondents, while grassland and cropland were considered as most prone to fire for $27 \%$ of respondents. Around $19 \%$ of sampled population indicated a potential of high risk of damage to constructions and infrastructure in case of a fire event, $44 \%$ as moderate risk of damage and $37 \%$ as low risk of damage. As a result, fire risk appeared to be underestimated in the WUI.

In the absence of proper accounting of fire suppression costs in Lebanon, $63 \%$ of sampled population estimated an average cost range of 0-2500 USD, 23\% of respondents estimated an average cost range of 2500-5000 USD per fire intervention, and only $14 \%$ of respondents estimated an average cost higher than 5000 USD. Also, $34 \%$ believed that fire hazard can be reduced primarily by increasing awareness, while $24 \%$ believed that fire hazard can be reduced by improving management of forest fuel. This indicated people's willingness to take active measures before fire events.

Perceptions of possible damages/impacts in case of a fire occurrence in the town of respondents are presented below (Figure 4). More specifically, 39\% of respondents anticipated a high impact on wood resources in case of a fire event in their towns. Also, 39\% of respondents expected a high impact on public health in case of a fire event. As such, wood is still considered as a valuable resource to the local communities while health and air quality issues remain a concern to people given previous health incidents related to smoke emission from fires.

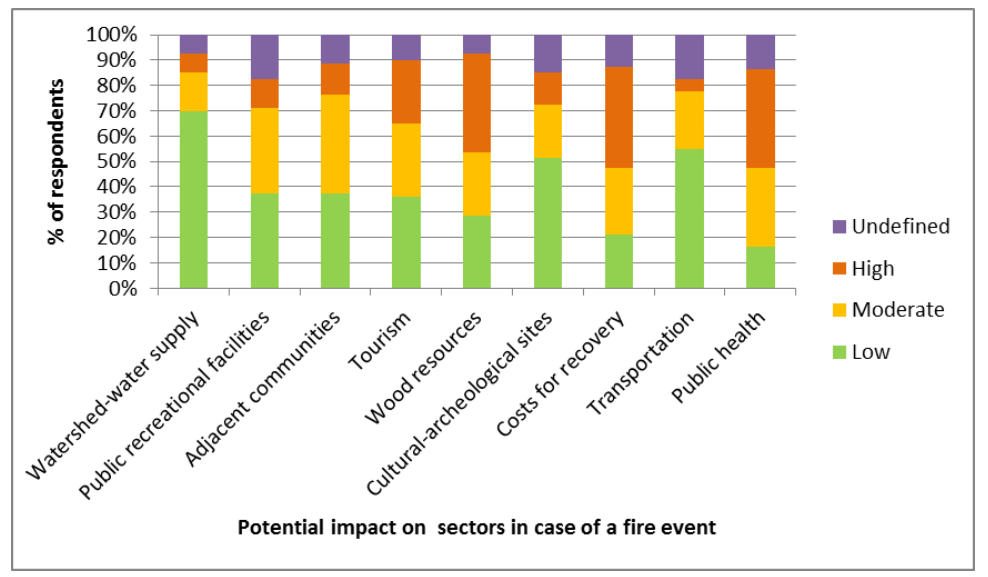

Figure 4 - Possible damages/impacts in case of a fire occurrence in the town of respondents

\section{Conclusions}

This work investigated the spatial distribution of fire risk at the fireshed level and conducted a socio-economic survey accordingly. Preliminary results showed how the public perceived fire as an environmental and socio-economic problem in areas characterized by high risk of fire. While all respondents were randomly selected from municipalities characterized by high risk of fires, the results of the survey showed that a relatively large number of people were not aware of the presence of high risk of fire in their towns. Also, surveyed people mostly expected losses and damages in wood resources in case of a fire event; while very few of them expected low impact on the watershed and water supply, knowing that the study area was part of a strategic and vulnerable watershed. In brief, the results highlighted the need to increase collaboration and coordination among agencies, landowners, and the local communities, while promoting priorities for fire risk management. Future 
work will include further analysis of the survey results for improved assessment of collected socioeconomic data.

\section{References}

Bahro B, Barber K, Sherlock J, Yasuda D (2007) Stewardship and Fireshed Assessment: A Process for Designing a Landscape Fuel Treatment Strategy. USDA Forest Service Gen. Tech. Rep. PSWGTR-203.

BGR/CDR (2008) Water Balance for the Groundwater Contribution Zone of Jeita Spring using WEAP. (Eds P Schuler, A Margane). PROJECT NO.: 2008.2162.9.

Finney MA (2001) Design of regular landscape fuel treatment patterns for modifying fire growth and behavior. Forest Science 47, 219-228.

Mitri G, Jazi M, McWethy D (2015) Assessment of wildfire risk in Lebanon using Geographic Objectbased image analysis. Photogrammetric Engineering \& Remote Sensing 81, 499-506. 